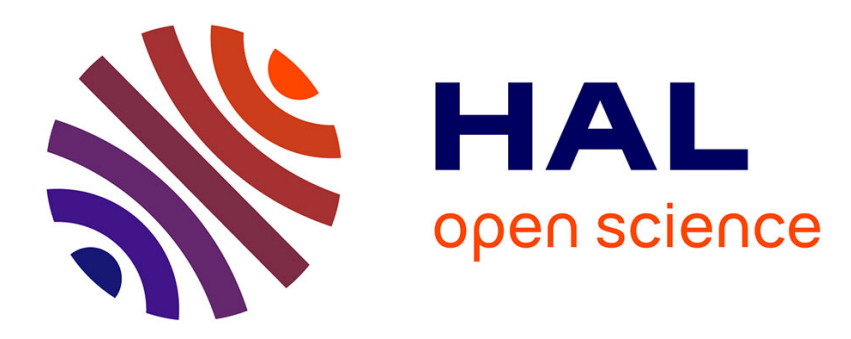

\title{
How big is the comeback? Japanese exchange rate pass-through assessed by Time-Varying FAVAR \\ Zakaria Moussa
}

\section{To cite this version:}

Zakaria Moussa. How big is the comeback? Japanese exchange rate pass-through assessed by TimeVarying FAVAR. 2016. hal-01282811

\section{HAL Id: hal-01282811 \\ https://hal.science/hal-01282811}

Preprint submitted on 4 Mar 2016

HAL is a multi-disciplinary open access archive for the deposit and dissemination of scientific research documents, whether they are published or not. The documents may come from teaching and research institutions in France or abroad, or from public or private research centers.
L'archive ouverte pluridisciplinaire HAL, est destinée au dépôt et à la diffusion de documents scientifiques de niveau recherche, publiés ou non, émanant des établissements d'enseignement et de recherche français ou étrangers, des laboratoires publics ou privés. 

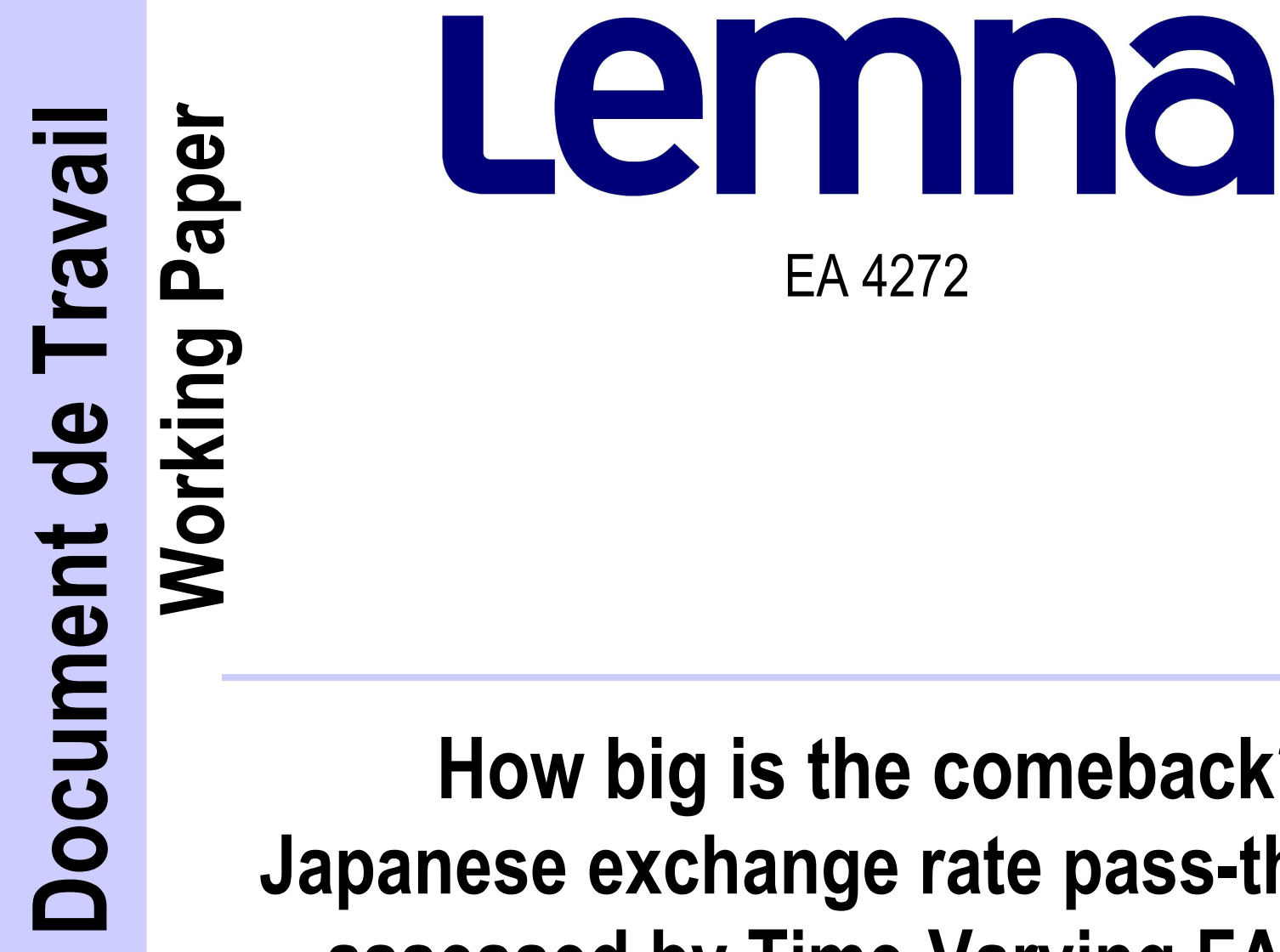

EA 4272

\section{How big is the comeback? Japanese exchange rate pass-through assessed by Time-Varying FAVAR}

\section{Zakaria Moussa*}

2016/03

$\left({ }^{*}\right)$ LEMNA, Université de Nantes

Laboratoire d'Economie et de Management Nantes-Atlantique Université de Nantes

Chemin de la Censive du Tertre - BP 52231

44322 Nantes cedex 3 - France

www.univ-nantes.frliemn-iae/recherche 


\title{
How big is the comeback? Japanese exchange rate pass-through assessed by Time-Varying FAVAR
}

\author{
ZAKARIA MOUSSA*
}

March 2, 2016

\begin{abstract}
We examine the evolution and the magnitude of exchange rate pass-through (ERPT) to Japanese prices. We employ the Time-Varying-Parameters Factor-Augmented Vector autoregression model (TVP-FAVAR), which enables us to include a large enough of data to better control for variables impacting prices and exchange rate. Our results confirm the decline in ERPT rates until the late 2000s and their resurgence in last years. Our findings provide additional support to the notion that exchange rates can impact import and domestic prices, possibly helping avoid deflation. We also find that the ERPT into aggregate prices can hide considerable variation in price sensitivity to exchange rates across stages of demand and industries. ERPT decreases along the pricing chain, from imported raw materials and intermediate goods prices to domestic prices. Finally, we find price sensitivity consistent throughout, indicating that incorporating extra information leads to more robust estimates.
\end{abstract} JEL classification: E31, F31, F41.

Keywords: exchange rate pass-through; Japan; import prices; domestic prices; TVP-FAVAR model.

*LEMNA, University of Nantes, France, zakaria.moussa@univ-nantes.fr. 


\section{Introduction}

The exchange rate pass-through (ERPT) in domestic prices has recently been attracting attention again. Exchange rates may offer a plausible alternative monetary policy instrument in the current zero interest rate environment. The global financial crisis forced most major central banks to employ unconventional monetary policy tools. These included quantitative and qualitative easing, alone or in combination, as well as an explicit commitment to maintain low nominal short-term interest rates.(Bernanke and Reinhart, 2004; Walsh, 2009; Woodford, 2012) There was skepticism regarding the employment of the exchange rate by central banks (McCallum, 2006), even thought this was part of the unconventional tools already proposed to the BoJ (McCallum, 2000, 2006; Svensson, 2001; Coenen and Wieland, 2003). Currently, exchange rate depreciation is increasingly used to fight deflation (Borio and Disyatat, 2010; Ishi et al., 2011; Franta et al., 2014; Shioji, 2012, 2014, 2015), Which raises the question of how high ERPT needs to be before this tactic is effective.

An extensive literature revealed the decline of the exchange rate pass-through into domestic prices across many countries from the early 1990s (Taylor, 2000; Campa and Goldberg, 2005; Goldberg and Campa, 2010; Sekine, 2006). Declining ERPT into Japanese domestic prices is explained in two main ways by empirical studies. Otani et al. (2003, 2006); Sekine (2006) blame it chiefly on changing price-setting behavior of Japanese firms and pricing to market by foreign suppliers. In contrast, Ito et al. (2015) claim that Japanese firms' choices of invoicing currency are the major driver of ERPT decline. They show that the increase in intra-firm trades results in more Local-Currency Pricing (LCP), which likely reduces exchange rate pass-through.

However, recent papers by Shioji (2012, 2014, 2015); Hara et al. (2015) provide evidence of the resurgence of exchange rate pass-through into Japanese domestic prices in recent years. Shioji (2012) explores how yen movements are transmitted to domestic prices by using disaggregate data either on import or on domestic prices. A rise in ERPT was detected again in the late 2000s, suggesting that the Bank of Japan's aggressive monetary easing, launched to support the Abenomics in 2012, might be more successful at defeating deflation 
through the impact of yen depreciation. Shioji $(2014,2015)$ attribute the resurgence of ERPT to changing production structure and an increasing share of imported intermediate goods in production. Moreover, Shioji (2015) shows that ERPT to consumer prices is more pronounced for frequently purchased goods. No investigation is made of a possible price setting behavior effect, as behavior is assumed to be unchanged over the sample period. Hara et al. (2015) provide additional evidence of recent comeback of ERPT. They put this down not only to a changing production structure, but also to price setting behavior, which may be a major factor in this resurgence.

One strand of the literature examines the impact of exchange rate shocks to import and domestic prices, using vector autoregression (VAR) models (Hahn (2003), Choudhri and Hakura (2006) and Ito and Sato (2008), among others). The notable advantage of VAR methodology, as explained in Ito and Sato (2008), is that it avoids the endogeneity problem inherent in single-equation pass-through estimation (Campa and Goldberg (2005), Goldberg and Campa (2010), Hara et al. (2015), among many others) and thus accounts for the interrelation between exchange rate and prices. More recently, a growing literature has been examining ERPT using Time-Varying Parameters (TVP)-VAR models. Coefficients and the variance-covariance matrix of error terms are allowed to vary over time, thus making it possible to identify changes in ERPT at each point in time. Shioji (2012) estimates different Time-Varying Parameters (TVP)-VAR models separately for different stages in the transmission of exchange rate movements along the Japanese pricing chain. Results show significant ERPT variability over time.

This paper reexamines the evolution of the exchange rate pass-through, extending Shioji (2012) in two principal respects using the TVP-FAVAR model developed by Koop and Korobilis (2010) over a data set spanning the period 1985Q1-2015Q2. First, as clearly stated in (Bernanke et al., 2005) and generally recognized, the limited information included in a simple VAR system can lead to bias estimation results. Adding more macroeconomic and financial information, which may affect either exchange rate or prices, has the potential to resolve many inconsistencies observed empirically. Biased estimates of the pass-through coefficient could arise if, for instance, aggregate demand, the size of the country, the pene- 
tration ratio, price-setting behavior of foreign exporters and monetary policy environment are excluded from the analysis (Taylor, 2000; Smets and Wouters, 2002; Devereux et al., 2004; Sekine, 2006). ${ }^{1}$ Moreover, relatedly, instead of estimating (TVP)-VAR models separately for different stages of the ERPT along the pricing chain, the (TVP)-FAVAR model allows us to analyze the effect of the exchange rate variations at different stages from import to domestic prices in a unified framework. Second, as pointed out by Sato (2014) and Shioji (2015), analyzing ERPT through aggregate prices masks a large variation in price elasticity to exchange rate movements across different stages of demand, as well as across industries or categories. Therefore, to explore and understand how exchange rate movements affect different prices throughout the Japanese economy, our study includes disaggregate prices both by stage of demand and by industry-breakdown on import and domestic price data series.

We report three main findings: First, our results clearly show that sensitivity to change in the exchange rate varies across disaggregate prices in terms of both magnitude and time variation. However, in most cases, price sensitivity follows a downward trend starting from 1985Q1 to the late 2000s, prices subsequently becoming more sensitive to exchange rate changes. This confirms the resurgence of ERPT detected in recent studies. Although sensitivity was still not particularly high, what is important is the trend shift starting from the late 2000s, which may become persistent in future. Second, the incomplete shortand long-run ERPT detected for different prices is decreasing along the pricing chain. In addition, the higher ERPT into import final goods, compared with raw and intermediate goods, suggests that the growing Japanese production network and invoicing choices may impact intra-firm trade in terms of price sensitivity to exchange rate movements. Overall, our results confirm the resurgence of ERPT to Japanese prices detected in the recent empirical literature, and provide additional support for the notion that exchange rates can impact import and domestic prices, thereby helping avoid deflation. Although not common to all disaggregate export prices, overall export price sensitivity therefore moves in the opposite direction from import and domestic producer price sensitivity, showing a

\footnotetext{
${ }^{1}$ Some anomalies are identified in Shioji (2012) when, for instance, the ERPT to import price significantly exceeds the unit or the export reaction puzzle.
} 
flatter upward trend throughout the sample period from almost zero percent in 1985Q1 to about $20 \%$ in the long-run. Japanese exporters increasingly pass on exchange rate movements to foreign importers. Finally, price sensitivity is consistent throughout our results, indicating that incorporating extra information leads to more robust estimates.

The paper is organized as follows. The next section presents the econometric methodology and the identification strategy and describes the data employed in the empirical investigation. Section 3 presents the empirical findings and section 4 concludes.

\section{Econometric Methodology}

\section{$2.1 \quad$ The model}

We adopt the TVP-FAVAR model proposed by Koop and Korobilis (2010) and Mumtaz (2010):

$$
Y_{t}=\alpha_{t}+\sum_{p=1}^{P} \beta_{t, p} Y_{t-p}+v_{t}
$$

where $Y_{t}=\left[\begin{array}{ll}F_{t} & E_{t}\end{array}\right]^{\prime} . Y_{t}$ contains unobserved factors $F_{t}$, and an observable factor $E_{t}$ of dimension $(\nu \mathrm{x} 1)$, which represents the effective exchange rate. The $((K+\nu) \mathrm{x} 1)$ vector of error terms $v_{t}$ is mean 0 with covariance matrix $\Omega_{t}$ of dimension $((K+\nu) \mathrm{x}(K+\nu))$. The unobservable factors, $F_{t}$ are estimated in a first step using a singular value decomposition of data and then they are included in the equation in a second step. These factors are extracted from $X_{t}$ is $(N \times 1)$, which in addition to import and domestic prices, contains financial data and variables related to economic activity and foreign variables. $X_{t}$ are assumed to be related to the unobservable factors $F_{t}$ and the observable factors $E_{t}$ as follows:

$$
X_{t}=\Lambda_{t}^{f} F_{t}+\Lambda_{t}^{E} E_{t}+e_{t}
$$

where $e_{t}$ are errors with mean zero and $\Psi=\operatorname{diag}\left(\exp \left(\psi_{1, t}\right), \cdots, \exp \left(\psi_{n, t}\right)\right)$ as variancecovariance matrix. The error terms $e_{t}$ are assumed to be either weakly correlated or uncorrelated; these can be interpreted as idiosyncratic components. $\Lambda^{f}$ and $\Lambda^{E}$ are the 
$(N \mathrm{x} K),(N \mathrm{x} \nu)$ matrices of factor loadings. ${ }^{2}$

The structural shocks are recovered from the reduced form innovations using the Cholesky decomposition of the variance-covariance matrix $\Omega_{t}=A_{t}^{-1} H_{t}\left(A_{t}^{-1}\right)^{\prime}$. The time-varying matrices $H_{t}$ and $A_{t}$ are defined as:

$$
H_{t} \equiv\left[\begin{array}{cccc}
h_{1, t} & 0 & \cdots & 0 \\
0 & h_{2, t} & \cdots & 0 \\
\vdots & \cdots & \ddots & \vdots \\
0 & 0 & \cdots & h_{(K+\nu), t}
\end{array}\right] \quad A_{t} \equiv\left[\begin{array}{cccc}
1 & 0 & \cdots & 0 \\
a_{21, t} & 1 & \ddots & \vdots \\
\vdots & \cdots & \ddots & 0 \\
a_{(K+\nu) 1, t} & \ddots & a_{(K+\nu) k, t} & 1
\end{array}\right]
$$

Following Primiceri (2005) and Koop and Korobilis (2010), all the parameters in equation 1 are assumed to evolve as random walks as follows: ${ }^{3}$

$$
\left\{\begin{array}{l}
B_{t}=\phi_{t-1}+\eta^{B_{t}} \\
a_{t}=a_{t-1}+\eta^{a_{t}} \\
\ln h_{i, t}=\ln h_{i, t-1}+\eta^{h_{t}}
\end{array}\right.
$$

where $B_{t}=\left[\begin{array}{ll}\alpha_{t} & \beta_{t, p}\end{array}\right]$ and $h_{i, t}$ evolve as geometric random walks. We assume that the innovation vectors $\eta_{t}^{\phi} \sim N\left(0, Q_{\phi}\right)$ and are independent from each other and from $e_{t}$ and $v_{t}$ and, where $\phi=\left[\begin{array}{lll}B_{t} & a_{t} & \ln h_{i, t}\end{array}\right]$.

\subsection{Estimation}

Following Koop and Korobilis (2010), we summarize the estimation method in this section. ${ }^{4}$ Before summarizing the basic algorithm, we need to explain our choice of estimation method. ${ }^{5}$ As in Koop and Korobilis (2010) and Korobilis (2013), we estimate the model using a two-step procedure. In the first step, the unobservable factors are estimated by

\footnotetext{
${ }^{2}$ Factors are estimated using the principal component method. For the model to be identified, we use the standard normalization implicit in the principal components, as in Bernanke et al. (2005), and take $C^{\prime} C / T=I$, where $C($.$) represents the common space spanned by the factors.$

${ }^{3}$ Following Korobilis (2013) and Mumtaz (2010), in this model factor loadings and variance-covariance matrix in equation 2 are not allowed to vary over time.

${ }^{4}$ Detailed description of the prior distribution and the sampling method is given in Koop and Korobilis (2010) .

${ }^{5}$ Our estimations are based on the latest version of TVP-FAVAR code provided by Koop and Korobilis (2010), where the corrigendum of Negro and Primiceri (2013) is taken into account
} 
the principal component technique described in Bernanke et al. (2005). In the second step, we estimate the VAR system consisting of the estimated factors and the Japanese effective exchange rate. ${ }^{6}$

Four extracted factors are selected for inclusion in the VAR system. This number of factors is chosen not only by checking for sensitivity of the results to the inclusion of different numbers of factors, but also by the test of Alessi et al. (2010). ${ }^{7}$

Bayesian estimation of the model is performed through the Gibbs sampler, the most appropriate method of dealing with the problem of estimating a highly dimensional parameter model. Here we summarize the basic algorithm, which involves the following steps:

1. Initialize factors, model parameters and hyperparameters. ${ }^{8}$

2. Simulate the TVP-FAVAR coefficients $B_{t}$ and the off-diagonal elements of the matrix $A_{t}$ using Carter and Kohn (1994)'s algorithm, ${ }^{9}$ except for $h$ which is simulated using Kim et al. (1998)(1998)'s algorithm.

3. Draw the hyperparameters $Q_{\eta^{h_{t}}}^{T}$ using the inverse gamma distribution and draw the remaining $Q_{\eta}^{T}$ from an inverse Wishart distribution.

4. Simulate the factors conditional on all other parameters using the method described by Kim and Nelson (2001).

5. Go to step 2 .

We take 100,000 Gibbs sampling replications and discard the first 80,000.

\footnotetext{
${ }^{6}$ An alternative estimation method is a one-step method through a state-space representation. However, and as well explained in Bernanke et al. (2005), Korobilis (2013) and Mumtaz and Surico (2009), this method is very computationally demanding, especially to estimate high-dimensional models like the TVPFAVAR model.

${ }^{7}$ As in Bernanke et al. (2005), we took the ad-hoc approach to choose the optimal number of factors. This is justified by the fact that, while the statistical identification determines the number of factors present in the dataset, it does not determine the number of factors to include in the VAR system. However, when we apply the refinement version of Bai and Ng (2002)'s test of Alessi et al. (2010), this also select the same number of factors. Results are provided in Figure 4 in Appendix B.

${ }^{8}$ For this step, we follow Primiceri (2005) and Koop and Korobilis (2010) and use an informative prior based on a training sample, corresponding to the first forty observations.

${ }^{9}$ We do check for stationarity of the estimated VAR coefficient and reject draws if nonstationary.
} 


\subsection{Data treatment and identification}

For our empirical application, we use 78 quarterly time series data spanning the period from 1975Q1 to 2015-Q2. ${ }^{10}$ The database contains Japanese disaggregate price indices: import, corporate goods, export and consumer price indices. As in Shioji (2012), and as Sato (2014) suggests, we use a disaggregate Domestic Corporate Good Price Index (DCGPI) for different stages, namely, raw, intermediate and final goods. We also introduce industrybreakdown CGPI series, as the transmission of exchange rate variations may also vary across industries. This may, for instance, indicate how the growing regional production network consisting of Japan and other Asian countries affects the degree of ERPT in different sectors. Moreover, as shown by Shioji (2014), ERPT could also differ with degree of frequency of purchase of consumer goods. We therefore include in the analysis CPI series for different goods representing frequently-purchased and less frequently-purchased goods.

In addition, in order to obtain accurate ERPT estimation, we include macroeconomic variables that affect ERPT as identified by (Taylor, 2000; Devereux et al., 2004). We add the output gap as a proxy for domestic demand shocks. The monetary aggregate and short term interest rates are included in order to take into account monetary policy effects on prices and on the ERPT (Devereux et al. (2004)). The crude oil price is used to control its effect on prices which could interfere with price reaction to exchange rate movements. Foreign variables related to activity for the United States and United Kingdom are proxies for world-wide demand. In addition, in order to take into account foreign price-setting behavior, we use two different proxies for the marginal cost of foreign exporters ${ }^{11}$. In the empirical literature, this is constructed either as the weighted average of trade partners' CPI, as in Marazzi et al. (2005) and Sekine (2006), or as unit labor cost, as in Campa and Goldberg (2005). In this paper, we take both measures. These variables are also necessary controls in estimating the exchange rate pass-through as argued by Campa and Goldberg (2005). We include the penetration ratio, calculated on the basis of the ratio between

\footnotetext{
${ }^{10}$ Since we use the first forty observations as a training sample in the estimation procedure, our sample actually started from 1985Q1 to 2015Q2.

${ }^{11}$ Foreign prices (unit labor cost) = (nominal effective exchange rate/ CPI(ULC)-based real effective exchange rate)* consumer price index excluding food and energy.
} 
imports and real GDP, as an indicator of competitive pressures and changes in import composition. Finally, inflation and exchange rate volatilities ${ }^{12}$ are included to control for the effects of the inflation environment (Taylor, 2000) and exchange volatility (Devereux et al., 2004) on ERPT.

Data treatment and transformation are performed as follows. First, the CPI series are adjusted for the consumption tax: each is regressed on dummies corresponding to the introduction of the tax in April 1989, and the subsequent two hikes in April 1997 and April 2014. Then, the series are de-seasonalized when necessary, using the X-12 procedure. Finally, data are transformed in order to make them stationary ${ }^{13}$, when necessary, using the first log-difference, and then demeaned and standardized.

Finally, as the FAVAR model is intended to measure monetary policy and its macroeconomic effects, some adaptations in terms of specification are required for our study on ERPT. Therefore, like Bernanke et al. (2005), we choose to distinguish between slowmoving variables, which are not affected by other shocks in the current period, and fastmoving variables which react contemporaneously to the exchange rate shocks. In this paper, we adopt the identification scheme of Bernanke et al. (2005) for monetary policy analysis, adapting it to ERPT analysis. Therefore, the first block, consisting of the slow-moving group, comprises variables such as oil price, output gap and foreign variables; the second block contains the nominal effective exchange rate; and the third block is the fast-moving group comprising domestic price variables.

\section{Empirical results}

This section reports and discusses the estimated time varying ERPT into different prices. The convention in the literature (see for instance Shioji (2012)), is to measure the elasticity

\footnotetext{
${ }^{12}$ Volatility is measured by the annual unconditional standard deviation.

${ }^{13}$ It would have been better to take account of Uhlig (2009) critique, and use heavy transformations especially on CPI series. However, as we need to calculate cumulative impulse response functions for price variables, cumulating twice the series transformed using second log-difference gives uninterpretable impulse response functions. We therefore adopt in this paper light transformations differencing price series only once. Note, however, that we did estimate the model with heavy transformations; when we compared cumulative impulse response functions of CPI series with those from soft transformations, the results were fairly similar.
} 
or ERPT rate based on (i) the cumulative impulse response functions of different prices to a positive exchange rate shock (indicating depreciation), and (ii) the impulse responses of the exchange rate to an exchange rate shock. ${ }^{14}$

\subsection{The first stage of ERPT: from exchange rate to import prices}

Figure 1 displays the rate of ERPT into the aggregate overall import price (IPI) as well as disaggregate import prices by stages of demand namely the import price index of raw materials (IP-RAW), intermediate (IP-INTERM) and final goods (IP-FG). The first common feature for all import prices stages is a decrease in both short- and long-run ERPT over time, from 1985 until the late 2000s. In the short run, ie. until the fourth quarter, ERPT into overall import price is incomplete (between $40 \%$ and $60 \%$ ), suggesting that the exchange rate movements are only partially passed instantaneously to import prices. This reflects mixed LCP and PCP behavior by firms, and is consistent with Betts and Devereux (2000)' theoretical findings: under imperfect competition and nominal rigidity, only a fraction of firms set their prices in the home currency $(\mathrm{PCP})$, the remainder setting prices in the foreign currency (LCP or PTM). As predicted by the theory, when the full effect of exchange rate movements is manifested, long-run ERPT increases gradually over horizons at each point of time. However, only at the start of the sample, in 1985, is the long-run ERPT into import prices virtually complete, except for raw materials (about 70\%). And once again, the long-run ERPT is decreases quite sharply over the 1990s and up to the late 2000s. Moreover, this result is common to all product categories, as shown in Figure 5. This well documented downward trend in ERPT is common to developed countries ${ }^{15}$ and can be explained by a changing world trade structure, inflation environment, or monetary policy framework.

However, another likely explanation for the evolving ERPT into imported, especially intermediate, good prices is the growing network of Japanese producer. As pointed out

\footnotetext{
${ }^{14}$ More exactly, pass-through rate is calculated according to: $E R P T_{s, t}=\frac{P_{s, t}}{E_{s, t}}$, where $P_{s, t}$ is the cumulative impulse response of a price variable at horizon $s$ in period $t$ and $E_{s, t}$ is the cumulative change of the nominal effective exchange rate at horizon $s$ in period $t$.

${ }^{15}$ For example, Campa and Goldberg (2005) for the United states, Otani et al. (2003) and Otani et al. (2006) for Japan, Mumtaz et al. (2006) for UK and Stulz (2007) for Switzerland.
} 
in Ito et al. (2015), intra-firm trade between subsidiaries and the head office in Japan is often invoiced in yen. Specifically, subsidiaries selling intermediate inputs to Japan tend to choose yen invoicing when there are low fluctuations in the exchange rate. This can explain both declining ERPT to intermediate goods prices and and thus to total import prices over time, and its resurgence during the Asian crisis. When faced with large fluctuations in their local currency, subsidiaries reduce yen invoicing transactions, thereby increasing ERPT to Japanese import prices. As we can see from different ERPT estimations, the Asian crisis significantly altered ERPT to all import prices. Exporters from neighboring economies, subsidiaries or not, transmitted about $60 \%$ to $75 \%$ of exchange rate changes into different import prices.

An additional interesting finding by Ito et al. (2015) is that the subsidiaries' choice of invoice currency depends on the type of export goods. Unlike intermediate imported goods, subsidiaries tend to reduce yen invoicing for finished goods exported to Japan. This may therefore explain the higher ERPT into imported final goods prices compared with raw and intermediate goods prices. ${ }^{16}$ Our result also confirms that of Fujii (2004), indicating that for imported final goods, the PCP theory is likely to apply. This suggests that, despite international competition firms exporting final goods to Japanese importers and consumers maintain a certain pricing power leading to nearly perfect long-run ERPT. A high proportion of imported final goods belong to sectors subject to high product differentiation and/or limited Japanese domestic competition, which may confer or strengthen the market and pricing power of foreign exporters, allowing them to pass on more of the exchange rate movements into Japanese imported final goods prices. Figure 10 shows that foreign prices ${ }^{17}$ become more sensitive to exchange rate movements starting from the late 2000s. This confirms the view that foreign exporters have become more likely to change their prices frequently in recent years, passing more exchange rate changes on to prices.

The second common feature is the reversing upward trend in import prices at all stages since the late 2000s. While the long-run ERPT to IPI of $40 \%$, observed at the end of the

\footnotetext{
${ }^{16}$ Particularly non-durable consumer and capital final goods. As Figure 5 shows, imported final goods' reaction to exchange rate variations is mostly governed by these type of goods.

${ }^{17}$ Figure 10 shows elasticities of the two measures of the theoretical notion of foreign prices used in Marazzi et al. (2005) and Campa and Goldberg (2005). Results are almost identical.
} 
Figure 1: Responses of import prices
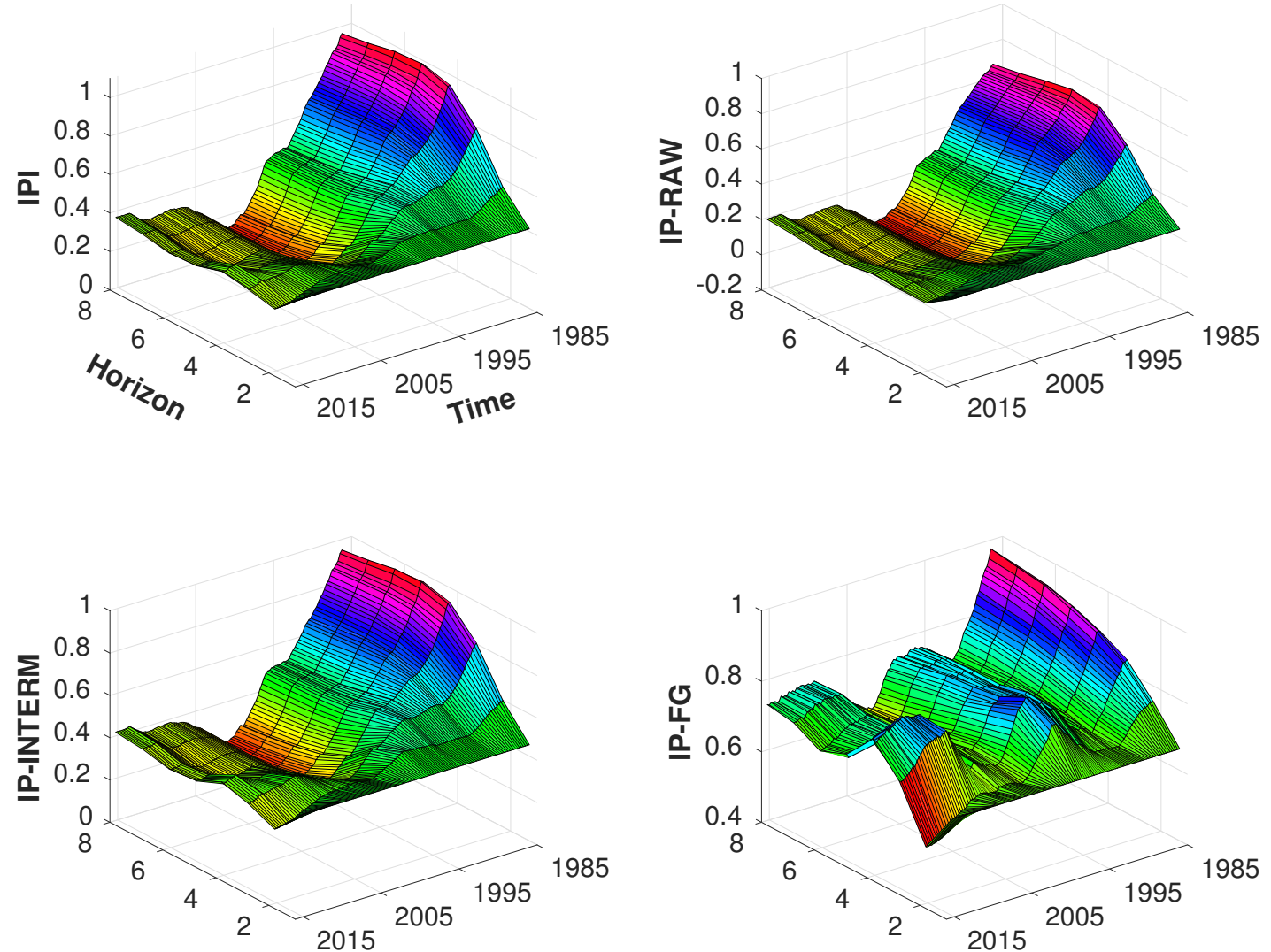

Note: three dimensional plots display the evolution of rates of exchange rate pass-through (ERPT) into import prices, over horizon (8 quarters) and over time from 1985Q1 to 2015Q2. Theses price elasticities are calculated based on impulse response functions to a one-standard-deviation positive exchange rate shock (equivalent to a depreciation). More precisely, $E R P T_{s, t}=\frac{P_{s, t}}{E_{s, t}}$, where $P_{s, t}$ is the cumulative impulse response of a price variable at horizon $s$ in period $t$ and $E_{s, t}$ is the cumulative change of the nominal effective exchange rate at horizon $s$ in period $t$. In the first row, we report ERPT into overall imported price (IPI) and import raw materia ls price (IP-RAW), and in the second row, into import intermediate materials price (IP-INTERM) and imported final goods price (IP-FG).

sample, may not seem particularly large, what is important is the trend shift starting in the late 2000s and which may be persistent in the future. This is consistent with the ERPT comeback view of Shioji (2012) and Hara et al. (2015) on Japanese import prices. This suggests that the yen's depreciation in recent years could regain its inflationary effect. The increased ERPT to prices for imported intermediate goods and raw materials is expected subsequently to affect domestic intermediate and final producer prices, in turn likely to impact retail prices. Moreover, very recent studies show that Japan's experience of ERPT resurgence after the financial crisis is not unique. Kristin Forbes and Nenova (2015) show that ERPT in UK increased between 2010 and 2013.

Still, our finding that ERPT to import prices is greatest for final goods (about $70 \%$ 
at the end of the sample) suggests that it is final goods that can most strongly impact domestic consumption prices by passing on exchange rate variations. Yen depreciation is likely to have more impact on Japanese consumer price inflation directly via imported final goods than indirectly via the production chain using imported raw materials and intermediate goods.

The reaction of real import elasticity (figure 10) to yen depreciation is in line with results from import prices. The ERPT into real imports is negative for all the period, namely between 1985Q1 and 2015Q2, and evolves in virtually the same way as the ERPT into import prices. As with import prices, the elasticity of real imports to exchange rate movements followed a downward trend until the late 2000s, subsequently reversing due to rising ERPT into import prices for the same period.

\subsection{The domestic side}

In this section, we investigate the effect that exchange rate movements have on both bystage-breakdown and industry-breakdown CGPI. This helps us identify the transmission mechanism which may differ both across stages of production and across industries. Retail prices, or consumer price index (CPI) data, are also included in the analysis, completing the domestic price chain. As shown in Shioji (2015), ERPT may differ between frequently and less frequently purchased items. This aspect is therefore taken into account in our analysis.

Figure 2 displays the degree of ERPT along the pricing chain for domestically produced goods, namely the ERPT to the CGPI for raw materials (raw), intermediate goods (INTERM) and final goods (FINALG) that are domestically produced. As with import prices, ERPT for domestic prices declined and followed a downward trend from the late 1980s until the late 2000s, with the exception of the 1997 Asian crisis period. ERPT rates for different types of goods still vary in terms of starting values. The long-run ERPT value was around $25 \%$ for raw materials at the beginning of the sample in 1985 , about

$30 \%$ for final goods and almost $70 \%$ for intermediate goods. From the late 2000s, however, ERPT rates began a new upward trend, although they remained low; $10 \%$ for raw and 
intermediate materials and even less than $10 \%$ for final goods in the long-run.

A close look at Figure 6 shows that ERPT rates also vary depending on the category of final goods, both in terms of level and of evolution over time. In the medium and long-run, while the ERPT rates for both consumer and consumer non-durable (CON-ND) goods have almost the same starting (30\%) and final values (5\%), the starting ERPT rate for capital goods (Capital) is only around 20\%. However, capital goods have recently shown almost the same long-run ERPT rates (between 5\% and 10\%). The ERPT for consumer non-durable goods differs completely: except at the very beginning of the sample, it never exceeds $10 \%$, remaining almost unchanged over time. The relatively high ERPT rate for consumer non-durables, which seems to govern the total final goods price, patterns, was predictable, since thsi category includes gasoline. Nevertheless, the ERPT rate is only about half that of ERPT to CGPI for intermediate goods. This is exactly in line with the results of Shioji (2012), indicating that domestic companies absorb in their profit margin (in their mark-ups) a large part of exchange rate through-put to intermediate goods domestically produced.

Overall, the analysis of the ERPT to different CGPI indicates that the pass-through of the yen depreciation quickly vanishes through the distribution chain. First, prices of domestically produced goods respond less to yen depreciation than imported goods, as the share of imported goods decreases along the distribution chain and also because domestic firms may choose not to fully transmit price changes of imported goods. Second, the relatively low ERPT to domestic final goods compared with domestic intermediate goods indicates that Japanese firms absorb the difference in their own mark-ups.

It is also worth noting that the industry-breakdown CGPI data analysis (Figure 7) identifies significant heterogeneity in ERPT rates across industries. These results support our decision to include industry-breakdown CGPI data, as suggested by Sato (2014). In so doing, we are able to take account of the growing Japanese production network that may impact price response to exchange rate movements of domestically produced goods, depending on the proportion of intra-firm imported goods in their production processes. For instance, at the beginning of the sample while the long-run ERPT rates (horizon 8) 
Figure 2: Responses of disaggregate CGPI prices
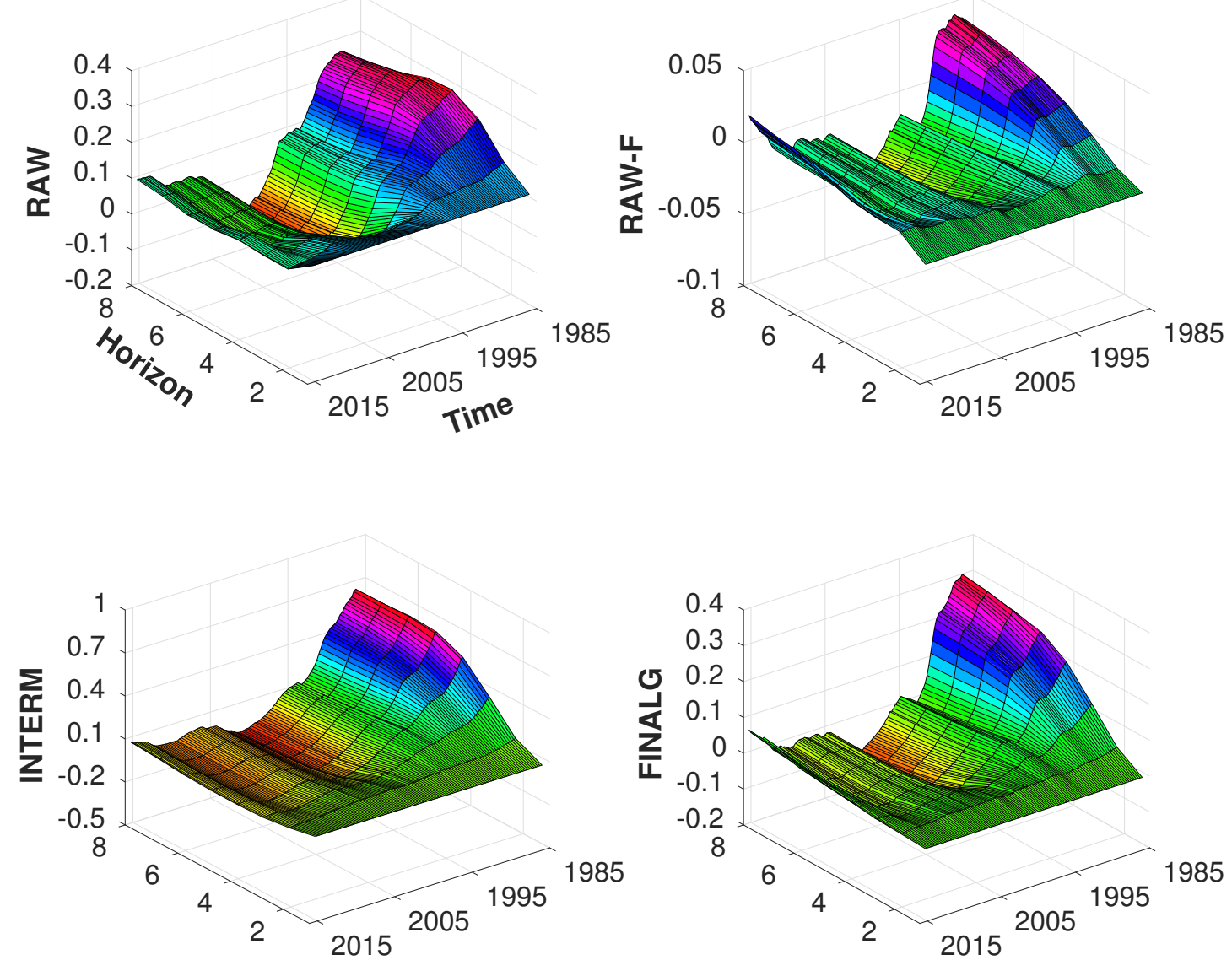

Note: three dimensional plots display the evolution of exchange rate pass-through (ERPT) rates into corporate goods price indices (CGPI), over horizon (8 quarters) and over time from 1985Q1 to 2015Q2. In the first row, we report ERPT rates into CGPI for raw materials (RAW) and for raw material of fuel (RAW-F), and in the second row, into CGPI for intermediate goods (INTERM) and for final goods (FINALG).

for plastic and chemical items are about $60 \%$, rates for other categories range from about $28 \%$ (FBTF and P-Machinery) to 15\% (ELECTRONIC). Clearly, industries which are more likely to use intra-firm imported intermediate goods, like machinery, and particularly the electronic and information and communication equipment sectors, experience weak ERPT to their prices. However, there is no difference in patterns of the ERPT evolution: the ERPT rate declined over time until the late 2000s and since then has followed a new upward trend, as previously found. The one exception is Information and Communications Equipment (IC-EQUIP), where ERPT rate behaves quite differently.

Figures 8 and 9 in the Appendix D show how different CPIs are influenced by exchange rate movements. As with import and CGPI prices, ERPT rates vary considerably across CPI series. A common feature of all ERPT rates for CPIs is their resurgence since the late 
2000s, showing that prices of frequently-purchased goods do not systemically appear to be more sensitive to yen changes. Also, Figures 8 and 9 show a variety of shapes for ERPT rates, which remain quite low for all prices, even negative for some, in both the frequentlyand the less frequently-purchased item groups. Among frequently-purchased items (Figure 9), the CPI for gasoline stands out as the highest long-run ERPT.

\subsection{The export side}

As export prices are expressed in JPY units, the rate of pass-through into export prices should be read as one minus given the elasticity in Figure 3. The second expected benefit from the yen depreciation is that of generating an export competitiveness boosting Japanese GDP. Assuming, of course, that the yen depreciation is strongly transmitted to Japanese export prices. Results shown in Figure 3 indicate a gradual rise in ERPT into overall export (EPI) and non-durable consumer goods prices over time, whereas the opposite picture emerges for capital and durable consumer good prices. Throughout the horizon, however, a common downward trend is found for ERPT into different export prices: fairly high short-run rates of ERPT of roughly $30 \%$ to $40 \%$ (slightly more for non-durable goods prices, between $40 \%$ and $50 \%$ ), which then rapidly diminish to reach a long-run level of some $20 \%$ within about four quarters.

Japanese intra-firm export has grown rapidly in recent years. Bernard et al. (2010), using U.S. trade transaction data, observe that in 2000, $74 \%$ of U.S. imports from Japan are intra-firm and traded between Japanese parents and U.S. subsidiaries. Moreover, the authors show that products traded predominantly via intra-firm transactions are either capital intensive or durable goods. ${ }^{18}$ On the other hand, Ito et al. (2013) focus on the invoicing choice of Japanese exporters and find that they tend to choose yen invoicing for intra-firm trade. This should therefore lower the ERPT into export prices, especially for capital and durable good prices. This intuition is supported by our results: capital and durable good price elasticities to yen depreciation decrease over time. However, the overall export price is increasing and seems to be governed by non-durable consumer good prices.

\footnotetext{
${ }^{18}$ page 5 , by industry
} 
Figure 3: Responses of disaggregate export prices
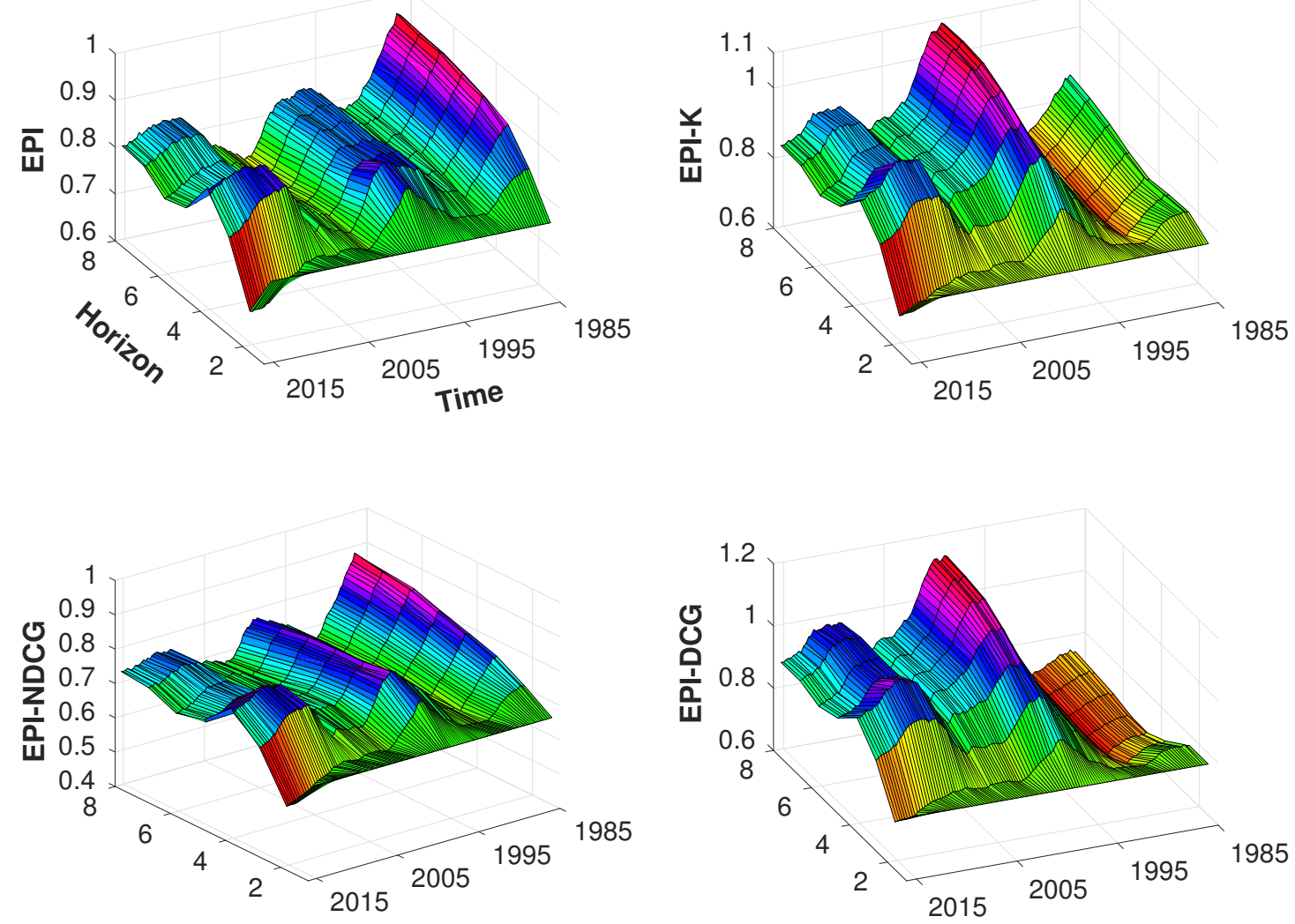

Note: three dimensional plots display the evolution of rates of exchange rate pass-through (ERPT) into export prices, over horizon (8 quarters) and over time from 1985Q1 to 2015Q2. In the first row, we report ERPT into overall export price (EPI) and export price of capital goods (EPI-K), and in the second row, into export price of non-durable (EPI-NDCG) and durable (EPI-DCG) consumer goods.

Although the ERPT into overall export prices may partly hide divergence in elasticity among export price categories, the very short-run ERPT remains on average relatively strong, indicating that export prices respond quite strongly and immediately to yen depreciations. However, contrary to expectations, Figure 10 shows that real export elasticity to yen depreciation moves over time in the opposite direction from that of the export price index. That is to say, when ERPT into export price is weak at the beginning of the sample, real exports respond relatively strongly, and conversely at the end of the sample. This means that exports were far more responsive to export prices than at present. Still, at the end of the sample, the yen depreciation resulted in a very short-lived increase in real exports (Figure 10), which rapidly returned to the initial zero level. 


\section{Conclusion}

Contributing to the current debate about the ability of exchange rate movements to impact domestic inflation and help escape deflation, this paper adopts the TVP-FAVAR model to re-examine the magnitude of the exchange rate pass-through (ERPT) into Japanese import, domestic and export prices. Compared with VAR and TVP-VAR models, widely used in previous studies on Japan, the TVP-FAVAR model offers two advantages. First, it allows us to incorporate a large amount of information, thus considering the macroeconomic variables affecting ERPT to prices such as output gap, oil price, openness of country, monetary policy instrument. At the same time, we can take into account different indirect transmissions of exchange rates to prices through other variables like mark-ups and marginal costs of trading partners. Second, the model allows us to incorporate many disaggregate prices series corresponding to different stages of demand and different categories and industries. It thereby becomes possible to evaluate the ERPT to different prices along the pricing chain and for different categories and industries in a unifying framework. Both advantages lead to more accurate estimation of the ERPT.

Our empirical results show that the evolution of ERPT assumes different patterns and magnitudes across disaggregate prices, justifying the incorporation of these variables in the analysis. The ERPT follows a downward trend starting from 1985Q1 to the late 2000s; subsequently, prices become more sensitive to exchange rate changes, confirming the comeback of the ERPT detected in recent empirical studies. These findings provide additional support to the notion that exchange rates can impact import and domestic prices, thereby possibly helping avoid deflation. Our results display only a little or no evidence of inconsistent price sensitivity, indicating that incorporating extra information leads to more accurate estimates.

Two interesting extensions to our analysis would be, first, to examine the effect of the yen appreciation in order to check whether price sensitivity is asymmetric (Delatte and López-Villavicencio, 2012). A second avenue worth exploring would be the notion that the underlying cause of exchange rate changes can impact the exchange rate through-put to 
prices, as put forward in Kristin Forbes and Nenova (2015) and Shambaugh (2008). 


\section{References}

Alessi, L., Barigozzi, M., Capasso, M., December 2010. Improved penalization for determining the number of factors in approximate factor models. Statistics \& Probability Letters 80 (23-24), 1806-1813.

Bai, J., Ng, S., January 2002. Determining the number of factors in approximate factor models. Econometrica 70 (1), 191-221.

Bernanke, B., Boivin, J., Eliasz, P. S., Jan 2005. Measuring the effects of monetary policy: A factor-augmented vector autoregressive (favar) approach. The Quarterly Journal of Economics 120 (1), 387-422.

Bernanke, B. S., Reinhart, V. R., 2004. Conducting monetary policy at very low short-term interest rates. American Economic Review 94 (2), 85 - 90.

Bernard, A. B., Jensen, J. B., Redding, S. J., Schott, P. K., May 2010. Intra-firm Trade and Product Contractibility (Long Version). American Economic Review Papers and Proceedings 100 (2), 444-48.

Betts, C., Devereux, M. B., February 2000. Exchange rate dynamics in a model of pricingto-market. Journal of International Economics 50 (1), 215-244.

Borio, C., Disyatat, P., 09 2010. Unconventional monetary policies: An appraisal. Manchester School 78 (s1), 53-89.

Campa, J. M., Goldberg, L. S., November 2005. Exchange rate pass-through into import prices. The Review of Economics and Statistics 87 (4), 679-690.

Carter, C. K., Kohn, R., 1994. On gibbs sampling for state space models. Biometrika 81 (3), $541-553$.

Choudhri, E. U., Hakura, D. S., June 2006. Exchange rate pass-through to domestic prices: Does the inflationary environment matter? Journal of International Money and Finance $25(4), 614-639$. 
Coenen, G., Wieland, V., July 2003. The zero-interest-rate bound and the role of the exchange rate for monetary policy in japan. Journal of Monetary Economics 50 (5), $1071-1101$.

Delatte, A.-L., López-Villavicencio, A., 2012. Asymmetric exchange rate pass-through: Evidence from major countries. Journal of Macroeconomics 34 (3), 833 - 844.

Devereux, M. B., Engel, C., Storgaard, P. E., 2004. Endogenous exchange rate pass-through when nominal prices are set in advance. Journal of International Economics 63 (2), 263291.

Franta, M., Holub, T., Král, P., Kubicová, I., Šmídková, K., Vašíček, B., 2014. Qualitative easing: How it works and why it matters. Research and Policy Notes 2014/03, Czech National Bank.

Fujii, E., 2004. Exchange Rate Pass-Through in the Deflationary Japan: How Effective is the Yen's Depreciation for Fighting Deflation? Tech. rep.

Goldberg, L. S., Campa, J. M., May 2010. The sensitivity of the cpi to exchange rates: Distribution margins, imported inputs, and trade exposure. The Review of Economics and Statistics 92 (2), 392-407.

Hahn, E., 2003. Pass-through of external shocks to euro area inflation. Tech. rep., working paper series / European Central Bank ; 243.

Hara, N., Hiraki, K., Ichise, Y., June 2015. Changing exchange rate pass-through in japan: Does it indicate changing pricing behavior? Tech. Rep. 15-E-4, Bank of Japan, bank of Japan Working Paper Series.

Ishi, K., Fujita, K., Stone, M. R., Jun 2011. Should unconventional balance sheet policies be added to the central bank toolkit? a review of the experience so far. IMF Working Papers 11/145, International Monetary Fund.

Ito, T., Sato, K., 2008. Exchange rate changes and inflation in post-crisis asian economies: Vector autoregression analysis of the exchange rate pass-through. Journal of Money, Credit and Banking 40 (7), 1407-1438. 
Ito, T., Sato, K., Shimisu, J., June 2013. Choice of invoicing currency: New evidence from a questionnaire survey of japanese export firms? Tech. Rep. 13-E-034, rIETI Discussion Paper Series.

Ito, T., Sato, K., Shimisu, J., July 2015. Choice of invoicing currency in global production and sales networks: the case of japanese overseas subsidiaries. Tech. Rep. 15-E-080, rIETI Discussion Paper Series.

Kim, C.-J., Nelson, C. R., November 2001. A bayesian approach to testing for markovswitching in univariate and dynamic factor models. International Economic Review $42(4), 989-1013$.

Kim, S., Shephard, N., Chib, S., July 1998. Stochastic volatility: Likelihood inference and comparison with arch models. Review of Economic Studies 65 (3), 361-93.

Koop, G., Korobilis, D., July 2010. Bayesian Multivariate Time Series Methods for Empirical Macroeconomics. Foundations and Trends(R) in Econometrics 3 (4), 267-358.

Korobilis, D., 04 2013. Assessing the transmission of monetary policy using time-varying parameter dynamic factor. Oxford Bulletin of Economics and Statistics 75 (2), 157-179.

Kristin Forbes, I. H., Nenova, T., November 2015. The shocks matter: improving our estimates of exchange rate pass-through. Tech. Rep. 43, Bank of England Discussion Paper, external MPC Unit.

Marazzi, M., Sheets, N., Vigfusson, R. J., Faust, J., Gagnon, J. E., Marquez, J. R., Martin, R. F., Reeve, T. A., Rogers, J. H., 2005. Exchange rate pass-through to u.s. import prices: some new evidence. Tech. rep.

McCallum, B. T., November 2000. Theoretical analysis regarding a zero lower bound on nominal interest rates. Journal of Money, Credit and Banking 32 (4), 870-904.

McCallum, B. T., enero-mar 2006. A monetary policy rule for automatic prevention of a liquidity trap. In: Monetary Policy with Very Low Inflation in the Pacific Rim, NBEREASE, Volume 15. NBER Chapters. National Bureau of Economic Research, Inc, pp. $9-42$. 
Mumtaz, H., Mar 2010. Evolving uk macroeconomic dynamics: a time-varying factor augmented var. Bank of England working papers 386, Bank of England.

Mumtaz, H., Surico, P., 02 2009. The transmission of international shocks: A factoraugmented var approach. Journal of Money, Credit and Banking 41 (s1), 71-100.

Mumtaz, H., Özlem Oomen, Wang, J., Nov 2006. Exchange rate pass-through into uk import prices. Bank of England working papers 312, Bank of England.

Negro, M. D., Primiceri, G. E., 2013. Time-varying structural vector autoregressions and monetary policy: a corrigendum. Tech. rep.

Otani, A., Shiratsuka, S., Shirota, T., October 2003. The decline in the exchange rate pass-through: Evidence from japanese import prices. Monetary and Economic Studies $21(3), 53-81$.

Otani, A., Shiratsuka, S., Shirota, T., March 2006. Revisiting the decline in the exchange rate pass-through: Further evidence from japan's import prices. Monetary and Economic Studies 24 (1), 61-75.

Primiceri, G. E., Jul 2005. Time varying structural vector autoregressions and monetary policy. Review of Economic Studies 72 (3).

Sato, K., 2014. Comment on "a pass-through revival". Asian Economic Policy Review 9 (1), $139-140$.

Sekine, T., Mar 2006. Time-varying exchange rate pass-through: experiences of some industrial countries. BIS Working Papers 202, Bank for International Settlements.

Shambaugh, J., June 2008. A new look at pass-through. Journal of International Money and Finance 27 (4), 560-591.

Shioji, E., June 2012. The evolution of the exchange rate pass-through in japan:a reevaluation based on time-varying parameter vars. Public Policy Review 8 (1), 67-92.

Shioji, E., 01 2014. A pass-through revival. Asian Economic Policy Review 9 (1), 120-138. 
Shioji, E., 2015. Time varying pass-through: Will the yen depreciation help japan hit the inflation target? Journal of the Japanese and International Economies 37, 43-58.

Smets, F., Wouters, R., 2002. Openness, imperfect exchange rate pass-through and monetary policy. Journal of Monetary Economics 49 (5), 947 - 981.

Stulz, J., 2007. Exchange rate pass-through in switzerland: Evidence from vector autoregressions. Tech. rep.

Svensson, L.-E.-O., February 2001. The zero bound in an open economy: A foolproof way of escaping from a liquidity trap. Monetary and Economic Studies 19 (S1), 277-312.

Taylor, J. B., June 2000. Low inflation, pass-through, and the pricing power of firms. European Economic Review 44 (7), 1389-1408.

Uhlig, H., December 2009. Comment on "how has the euro changed the monetary transmission mechanism?". In: NBER Macroeconomics Annual 2008, Volume 23. NBER Chapters. National Bureau of Economic Research, Inc, pp. 141-152.

Walsh, C. E., 2009. Using monetary policy to stabilize economic activity. Proceedings Economic Policy Symposium - Jackson Hole, 245-296.

Woodford, M., 2012. Methods of policy accommodation at the interest-rate lower bound. Proceedings - Economic Policy Symposium - Jackson Hole, 185-288. 


\section{A Dataset}

\section{Table 1: Variable list}

Data are extracted from Reuters EcoWin database. The transformation codes (T) are: 1: no transformation; 5: first difference of logarithm.

\begin{tabular}{llll}
\hline$\#$ & T & Mnemonic & \multicolumn{1}{c}{ Description } \\
\hline 1 & 5 & WORLDOIL & World Commodity Prices: Crude Oil NADJ \\
2 & 5 & USGDP & US GDP (AR) CONA \\
3 & 5 & UKGDP & UK GDP At Market Prices (CVM) CONA \\
4 & 5 & FFR & US Federal Funds Rate NADJ \\
5 & 5 & UKrate & UK short term rate \\
7 & 5 & M2CD & JP Money Supply: M2 (METHO-BREAK, APR. 2003) CURA \\
8 & 1 & TOPIX & JP Share Prices: TSE TOPIX ALL SHARES INDEX \\
9 & 1 & OUTPUTGAP & Output gap provided by the BoJ \\
10 & 5 & RGFCFPNR & JP Private Non-Residential GFCF (Real) (AR) CONA \\
11 & 5 & RFDEXP & JP Final Domestic Expenditure (Real) (AR) CONA \\
12 & 5 & RTDEXP & JP Total Domestic Expenditure (Real) (AR) CONA \\
\hline 13 & 5 & NEER & Nominal/Effective Exchange Rates (2010=100) NEER \\
\end{tabular}

\begin{tabular}{|c|c|c|c|}
\hline \multicolumn{4}{|r|}{ Fast moving } \\
\hline 14 & 5 & FOREIGNP & Foreign prices \\
\hline 15 & 5 & FOREIGNULC & Foreign Unit Labor Cost \\
\hline 16 & 5 & IMPORTALL & Import Price Index/yen basis. All commodities \\
\hline 17 & 5 & IMPORTPCNG & Import Price Index/Group/Petroleum, coal \& natural gas \\
\hline 18 & 5 & IMPORTFF & Import Price Index/Group/Foodstuffs \& feedstuffs \\
\hline 19 & 5 & IMPORTRAW & Import Price Index/Raw materials \\
\hline 20 & 5 & IMPORTRAWP & Import Price Index/Raw materials/Raw materials for processing \\
\hline 21 & 5 & IMPORTINTERM & Import Price Index/Intermediate materials \\
\hline 22 & 5 & IMPORTINTERSFG & Import Price Index/Intermediate materials/Semi-finished goods \\
\hline 23 & 5 & IMPORTINTERFE & Import Price Index/Intermediate materials/Fuel \& energy \\
\hline 24 & 5 & IMPORTFG & Import Price Index/Final goods \\
\hline 25 & 5 & IMPORTFGCG & Import Price Index/Final goods/Capital goods \\
\hline 26 & 5 & IMPORTFGCONSG & Import Price Index/Final goods/Consumer goods \\
\hline 27 & 5 & IMPORTFGCGD & Import Price Index/Final goods/Durable consumer goods \\
\hline 28 & 5 & IMPORTFGCGND & Import Price Index/Final goods/Nondurable consumer goods \\
\hline 29 & 5 & CGPIRM & CGPI (2010 Base)/Raw materials (Domestic goods) \\
\hline 30 & 5 & CGPIRMP & CGPI (2010 Base)/Raw materials/Raw materials for processing \\
\hline 31 & 5 & CGPIRMF & CGPI (2010 Base)/Raw materials/Fuel \\
\hline 32 & 5 & CGPIRMOTH & CGPI (2010 Base)/Raw materials/Other raw materials \\
\hline 33 & 5 & CGPIINTM & CGPI (2010 Base)/Intermediate materials (Domestic goods) \\
\hline 34 & 5 & CGPIINTMSFG & CGPI (2010 Base)/Intermediate materials/Semi-finished goods \\
\hline 35 & 5 & CGPIINTMFE & CGPI (2010 Base)/Intermediate materials/Fuel \& energy \\
\hline 36 & 5 & CGPIINTOTH & CGPI (2010 Base)/Other intermediate materials \\
\hline
\end{tabular}




\begin{tabular}{|c|c|c|c|}
\hline 37 & 5 & CGPIFG & CGPI (2010 Base)/Final goods \\
\hline 38 & 5 & CGPIFGCAPG & CGPI (2010 Base)/Final goods/Capital goods \\
\hline 39 & 5 & CGPIFGCONSG & CGPI (2010 Base)/Final goods/Consumer goods \\
\hline 40 & 5 & CGPIFGDCONSG & CGPI (2010 Base)/Final goods/Durable consumer goods \\
\hline 41 & 5 & CGPIFGNDCONSG & CGPI (2010 Base)/Final goods/Nondurable consumer goods \\
\hline 42 & 5 & FBTF & CGPI: Food, beverages, tobacco \& feedstuffs \\
\hline 43 & 5 & TEXTILE & CGPI: Textile products \\
\hline 44 & 5 & CHEMICAL & CGPI: Chemicals \& related products \\
\hline 45 & 5 & PLASTIC & CGPI: Plastic products \\
\hline 46 & 5 & CERSTCL & CGPI: Ceramic, stone \& clay products \\
\hline 47 & 5 & BOMACH & CGPI: Business oriented machinery \\
\hline 48 & 5 & INFCMEQUIP & CGPI: Information \& communications equipment \\
\hline 49 & 5 & TPTEQUIP & CGPI: General purpose machinery \\
\hline 50 & 5 & PRDMACH & CGPI: Production machinery \\
\hline 51 & 5 & ELECCOMP & CGPI: Electronic components \& devices \\
\hline 52 & 5 & ECMACHEQUIP & CGPI: Electrical machinery \& equipment \\
\hline 53 & 5 & JPCPIEFAF & CPI: All Items Less Fresh Food NADJ \\
\hline 54 & 5 & JPCPIEIAF & CPI: All Items Less Imputed Rent NADJ \\
\hline 55 & 5 & JPCPIGLAF & CPI: All items NADJ \\
\hline 56 & 5 & JPCPIEFFF & CPI: Food Less Fresh Food NADJ \\
\hline 57 & 5 & JPCPIFDAF & CPI: Food NADJ \\
\hline 58 & 5 & JPCPIRXIF & CPI: Rent Less Imputed Rent NADJ \\
\hline 59 & 5 & JPCPPVSWF & CPI: Processed Vegetables \& Seaweeds NADJ \\
\hline 60 & 5 & JPCPIUEAF & CPI: Electricity NADJ \\
\hline 61 & 5 & JPCPIACAF & CPI: Clothes NADJ \\
\hline 62 & 5 & JPCPIUGAF & CPI: Gas NADJ \\
\hline 63 & 5 & JPCPIRTAF & CPI: Rent NADJ \\
\hline 64 & 5 & JPCPGASAF & CPI: Gasoline NADJ \\
\hline 65 & 5 & JPCPAUTAF & CPI: Automobiles NADJ \\
\hline 66 & 5 & JPCPNWPAF & CPI: Newspapers NADJ \\
\hline 67 & 5 & JPCPIHHAF & CPI: Domestic Services NADJ \\
\hline 68 & 5 & JPCPIDRAF & CPI: Durable Goods NADJ \\
\hline 69 & 5 & EXPPALL & CGPI (2010 Base)/ Export Price Index (yen basis) \\
\hline 70 & 5 & EXPPCAPG & CGPI (2010 Base)/ Exports/Capital goods \\
\hline 71 & 5 & EXPPCONSG & CGPI (2010 Base)/Exports/Consumer goods \\
\hline 72 & 5 & EXPPDCG & CGPI (2010 Base)/ Exports/Durable consumer goods \\
\hline 73 & 5 & EXPPNDCG & CGPI (2010 Base)/ Exports/Nondurable consumer goods \\
\hline 74 & 5 & WAGE & JP Labour Markets: Wage Rates NADJ \\
\hline 75 & 5 & REXPORT & Real Export, Unit CY2010 $=100$ \\
\hline 76 & 5 & RIMPORT & Real Import, Unit CY2010 $=100$ \\
\hline 77 & 5 & TOT & JP Terms of Trade Index NADJ \\
\hline 78 & 5 & PRATIO & $\begin{array}{l}\text { Import Penetration Ratio (the share of imports of goods and services in } \\
\text { real GDP) }\end{array}$ \\
\hline
\end{tabular}




\section{B Number of factor test}

Figure 4: Estimated number of factors

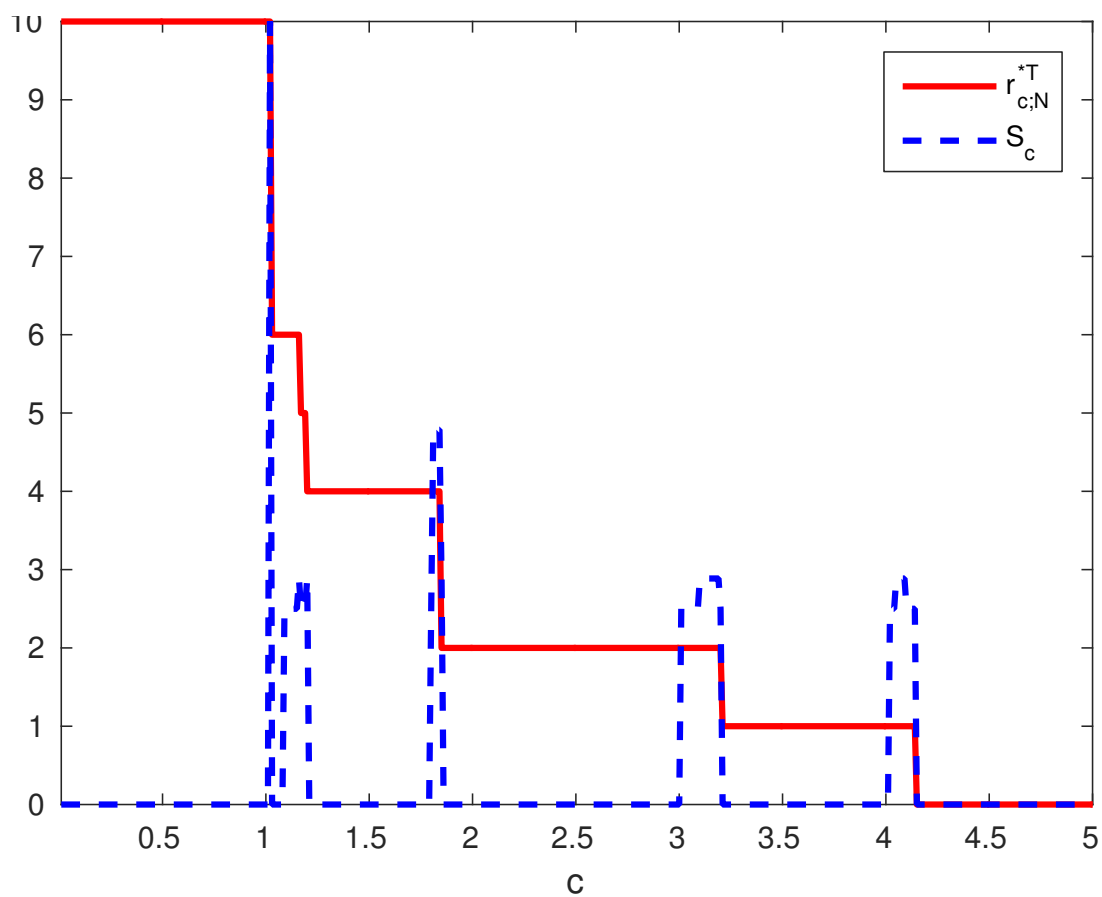

Note: Dashed line represents the suggested number of factors $r_{c}$ and the solid line is a measure of the instability of $r_{c}$. The number must correspond to the smallest value of $c$ for which both a plateau of the dashed line and a zero of the solid line occur. In this sens, Bai and Ng (2002) criteria constitute only a special case when $c=1$. This refined test suggests therefore 2 factors for our dataset. Fuller detail on this approach is given in Alessi et al. (2010).

\section{Disaggregate Import Prices}



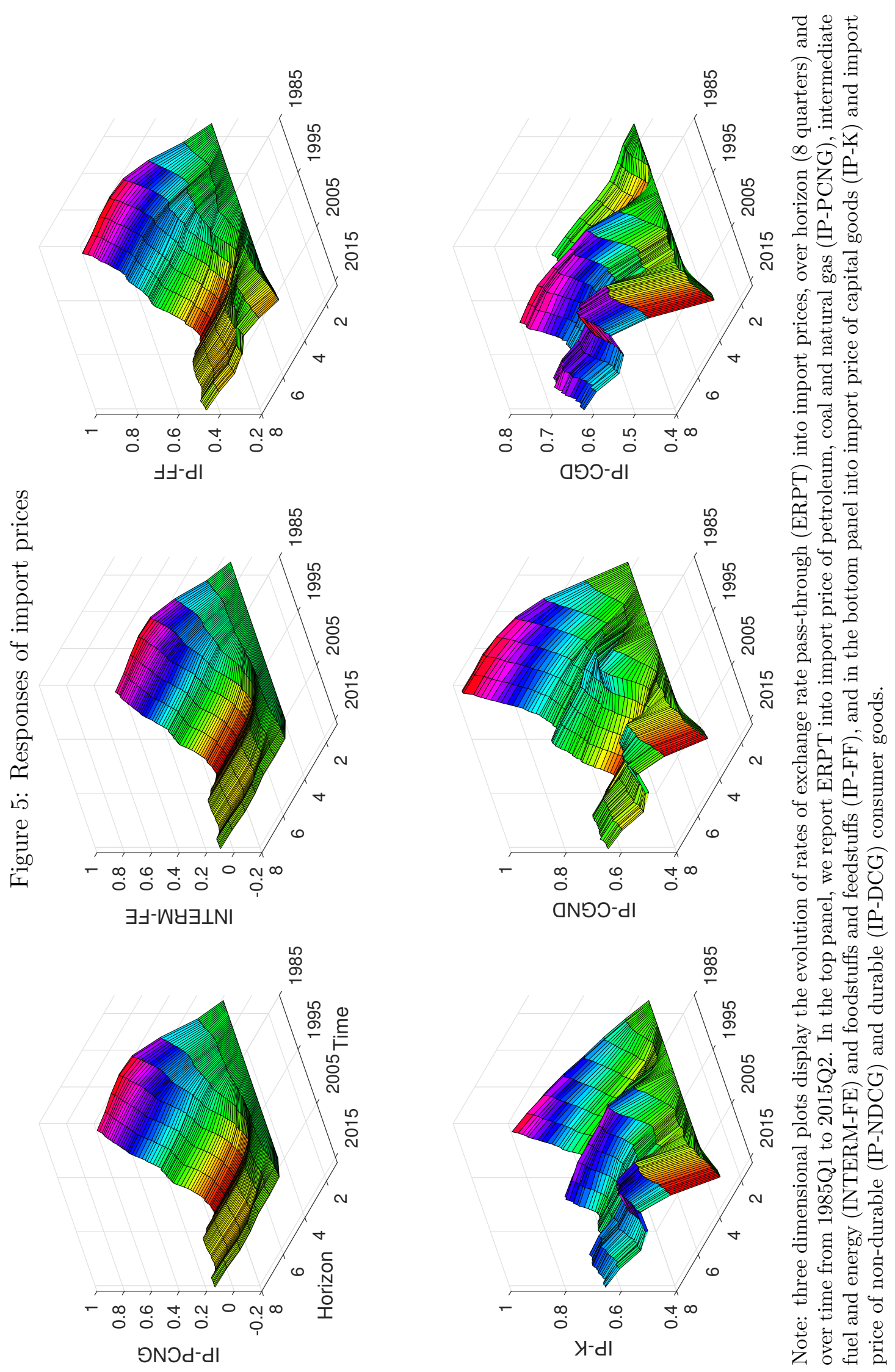


\section{Domestic side}

Figure 6: Responses of disaggregate domestic prices
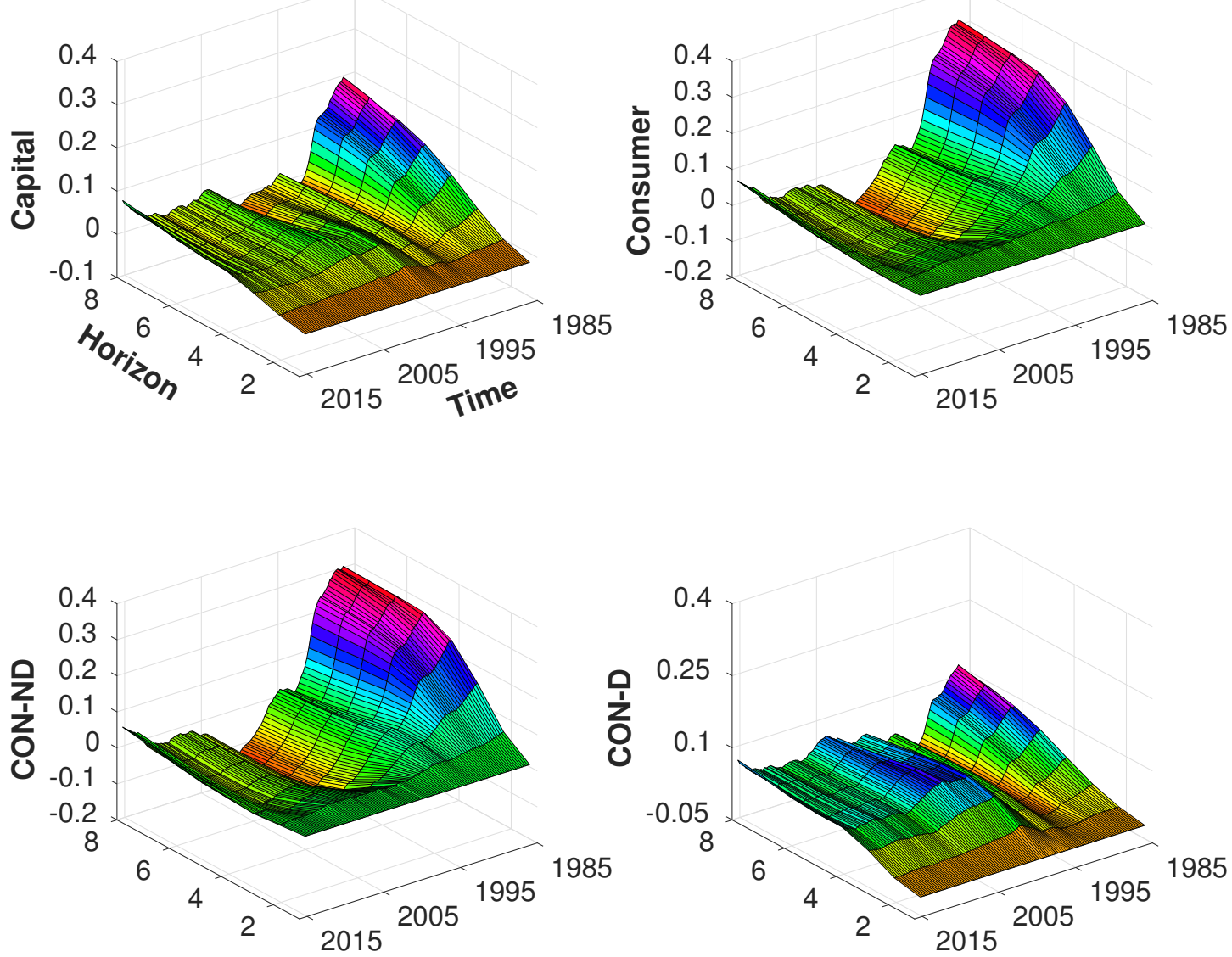

Note: three dimensional plots display the evolution rates of exchange rate pass-through (ERPT) into corporate goods price indices (CGPI), over horizon (8 quarters) and over time from 1985Q1 to 2015Q2. In the first row, we report ERPT into CGPI for capital goods (Capital) and for consumer goods (Consumer), and in the second row, into CGPI for consumer non-durable (CON-ND) and durable goods (CON-D). 

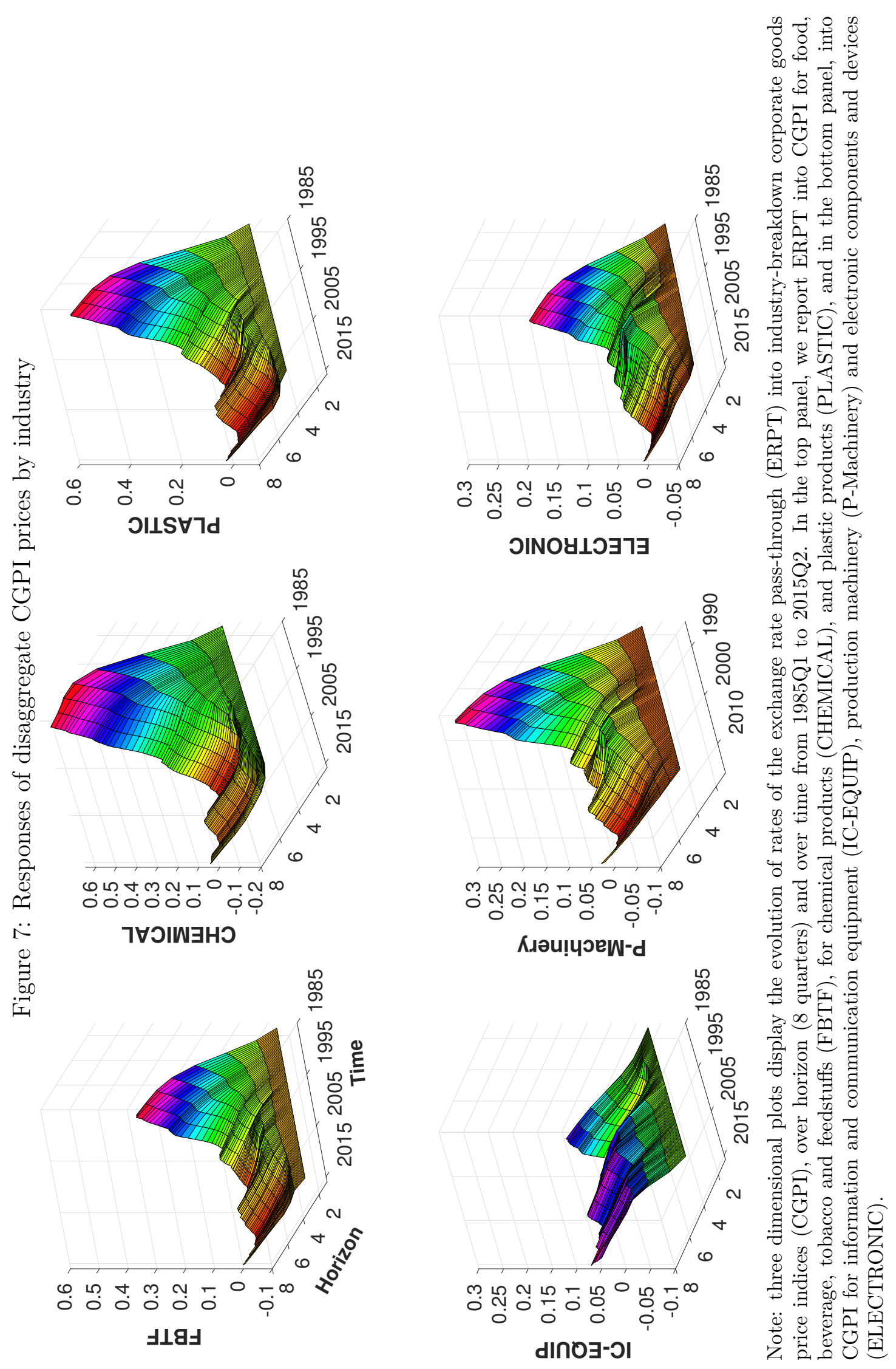
Figure 8: Responses of CPI for less frequent purshased items
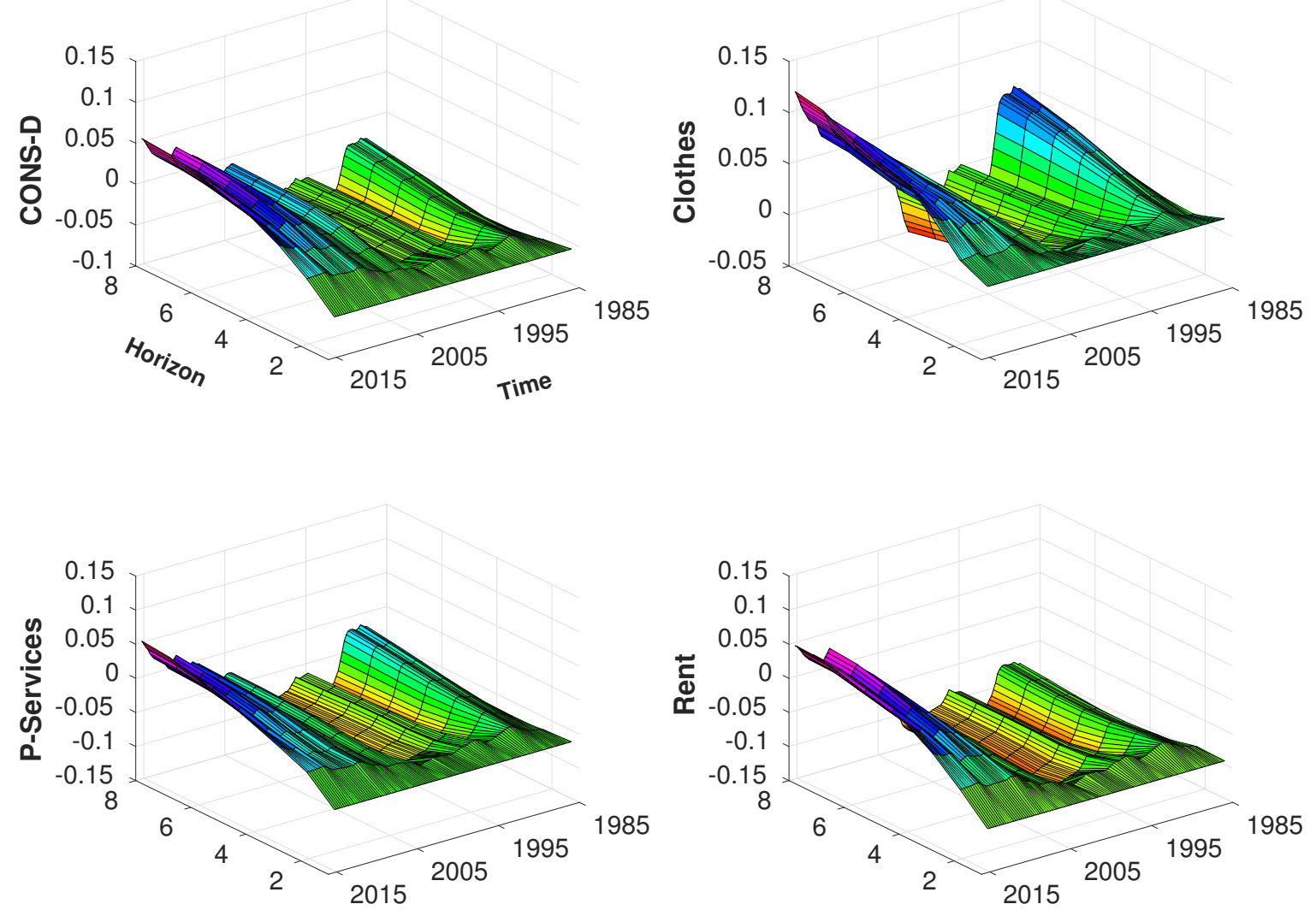

Note: three dimensional plots display the evolution of rates of the exchange rate pass-through (ERPT) into consumer price indices (CPI) for less frequent purchased items, over horizon (8 quarters) and over time from 1985Q1 to 2015Q2. In the first row, we report ERPT into CPI for durable consumer goods (CONS-D) and for clothes, and in the second row, into CPI for domestic services (P-services) and for rent. 

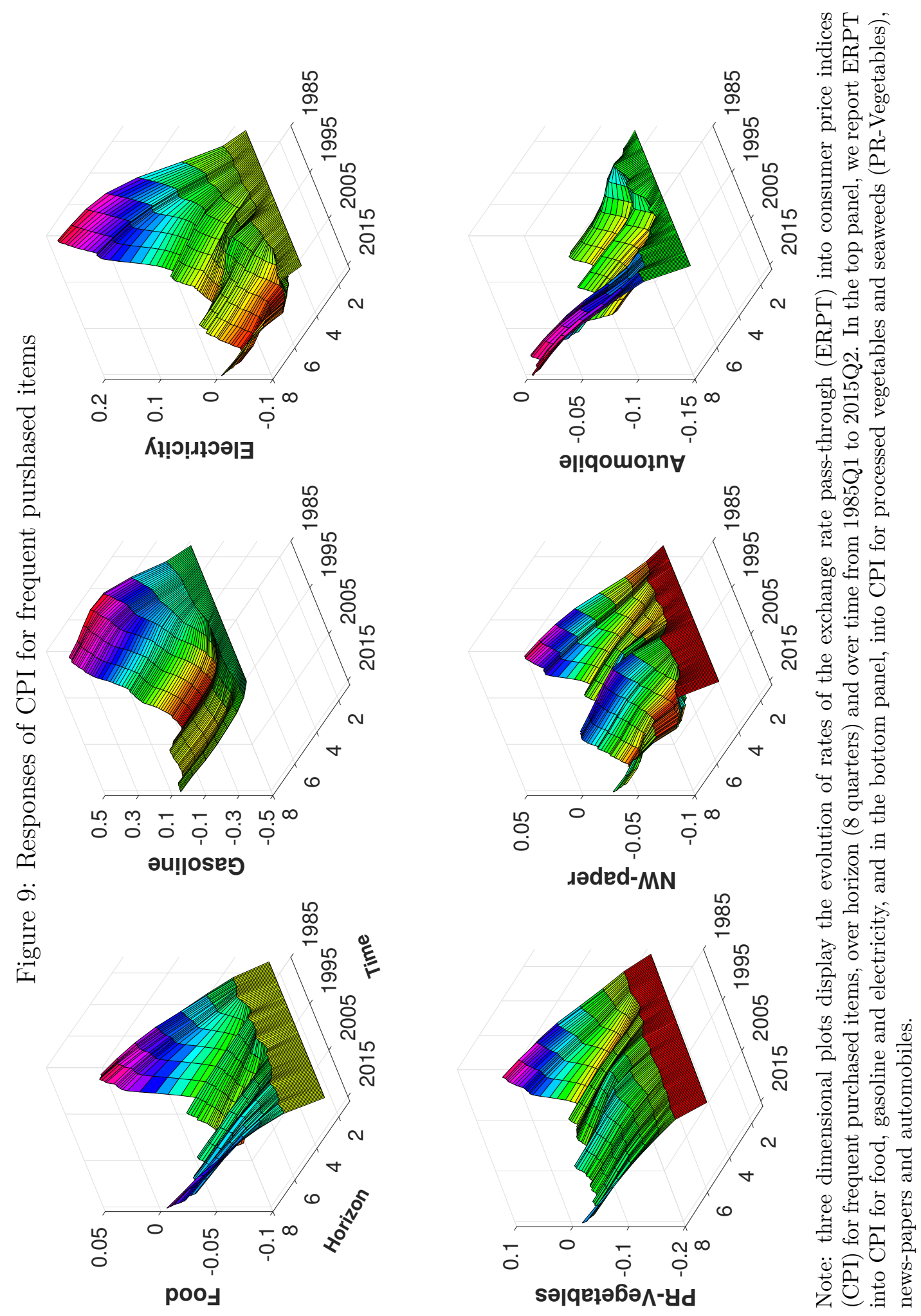
Figure 10: Responses of activity variables
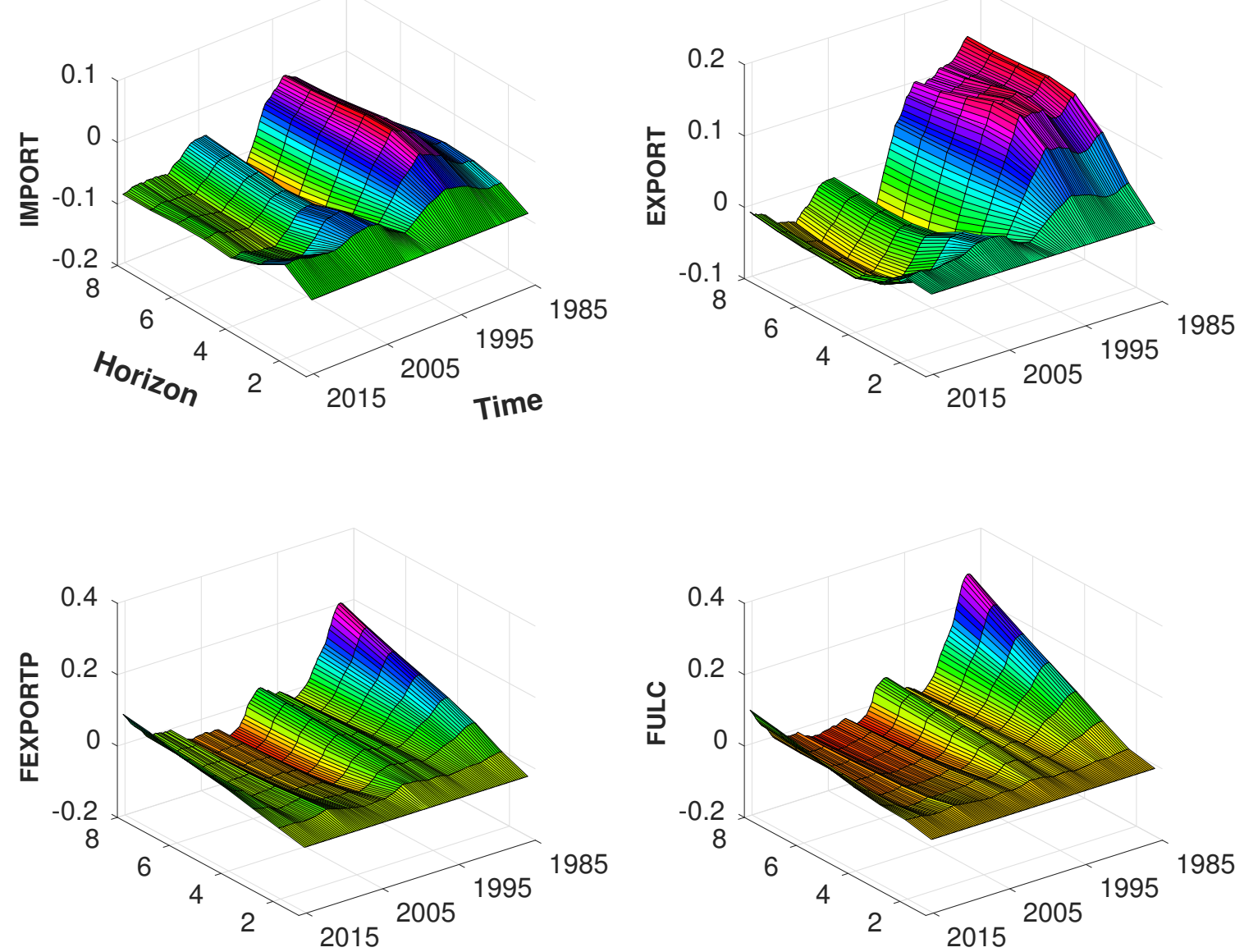

Note: three dimensional plots display the evolution of rates of the exchange rate pass-through (ERPT) into real import and real export and into the two measures of foreign prices, namely the CPI-based real effective exchange rate (FEXPORTP) and the ULC-based REER (FULC), over horizon (8 quarters) and over time from 1985Q1 to 2015Q2. 